\title{
(E)-2-(1-Cyano-2-methoxy-2-oxoethylidene)-3,4-dioxo-1- (pyridin-1-ium-1-yl)cyclobutan-1-ide
}

\author{
Johann Grünefeld ${ }^{1, *}$, Conrad Kunick ${ }^{1}$ (1) and Peter G. Jones ${ }^{2}$ \\ 1 Institut für Medizinische und Pharmazeutische Chemie, Technische Universität Braunschweig, \\ 38106 Braunschweig, Beethovenstraße 55, Germany; c.kunick@tu-bs.de \\ 2 Institut für Anorganische und Analytische Chemie, Technische Universität Braunschweig, \\ 38106 Braunschweig, Hagenring 30, Germany; p.jones@tu-bs.de \\ * Correspondence: j.gruenefeld@tu-bs.de
}

Received: 23 June 2017; Accepted: 31 July 2017; Published: 11 August 2017

Abstract: (E)-2-(1-Cyano-2-methoxy-2-oxoethylidene)-3,4-dioxo-1-(pyridin-1-ium-1-yl)cyclobutan-1-ide was obtained by a three-component reaction of squaric acid dichloride with pyridine and methyl cyanoacetate.

Keywords: pyridinium ylide; squaric acid; pseudooxocarbon

\section{Introduction}

Oxocarbons are a family of aromatic monocyclic anions of the general formula $\left[\mathrm{C}_{n} \mathrm{O}_{n}\right]^{-\mathrm{m}}$ and related compounds [1]. For derivatives in which the oxygen atoms are replaced by heteroatoms such as nitrogen or sulfur, or by substituents such as a dicyanomethylene group, the term "pseudooxocarbons" is used [2].

The anion of squaric acid (3,4-dihydroxycylobut-3-ene-1,2-dione) is the most prominent representative of the oxocarbons. Due to their photoelectrical properties, mesoionic compounds derived from squaric acid, e.g., squaraines, exhibit practical applications in solar cell technology $[3,4]$. Pyridinium ylides of squaric acid are structurally related to squaraines and thus may be utilized in a similar manner $[5,6]$. These compounds can be prepared by the reaction of squaric acid dichloride with pyridine and water $[7,8]$. If, instead of water, $N$-nucleophiles such as cyanamide or sulfonamides are used, pseudooxocarbon ylides are obtained [9]. We have succeeded in preparing the pseudooxocarbon ylide 4 by reaction of squaric acid dichloride (1) with pyridine (2) and methyl cyanoacetate (3) as C-nucleophile (Scheme 1).<smiles>O=c1c(Cl)c(Cl)c1=O</smiles>

1<smiles>c1ccncc1</smiles>

2<smiles>COC(=O)CC#N</smiles>

3

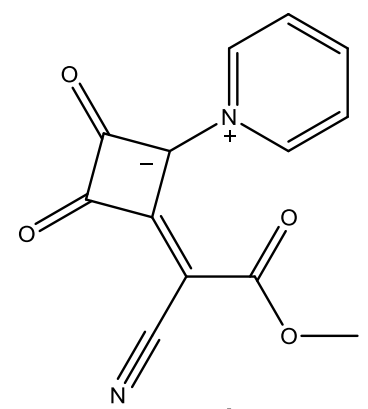

4

Scheme 1. Synthesis of the title compound 4. 


\section{Results and Discussion}

Compound 4 was prepared in accordance with the procedure described for the synthesis of other pyridinium ylides of squaric acid by slowly adding pyridine to a solution of the other two components in anhydrous dichloromethane [8,9]. The best results were obtained when the reaction temperature was maintained at $0{ }^{\circ} \mathrm{C}$ and contact with atmospheric moisture was avoided. Crystallization of the crude isolated material from a DMF/methanol mixture yielded the product as the $(E)$-configurated diastereomer, as was shown by an X-ray structure analysis of a single crystal (Figure 1). The central ring and its immediate substituents $(\mathrm{C} 1$ to $\mathrm{C} 4, \mathrm{~N} 1, \mathrm{O} 1, \mathrm{O} 2)$ are coplanar with a mean deviation of only $0.01 \AA$; the atom C10 lies $0.10 \AA$ outside this plane. The atom grouping $\mathrm{C} 10$ to $\mathrm{C} 13, \mathrm{O} 3, \mathrm{O} 4, \mathrm{~N} 2$ also forms a plane (mean deviation $0.025 \AA$ ) and this subtends an interplanar angle of $5^{\circ}$ to the central plane. Finally, the pyridine substituent makes an angle of $54^{\circ}$ to the central plane.

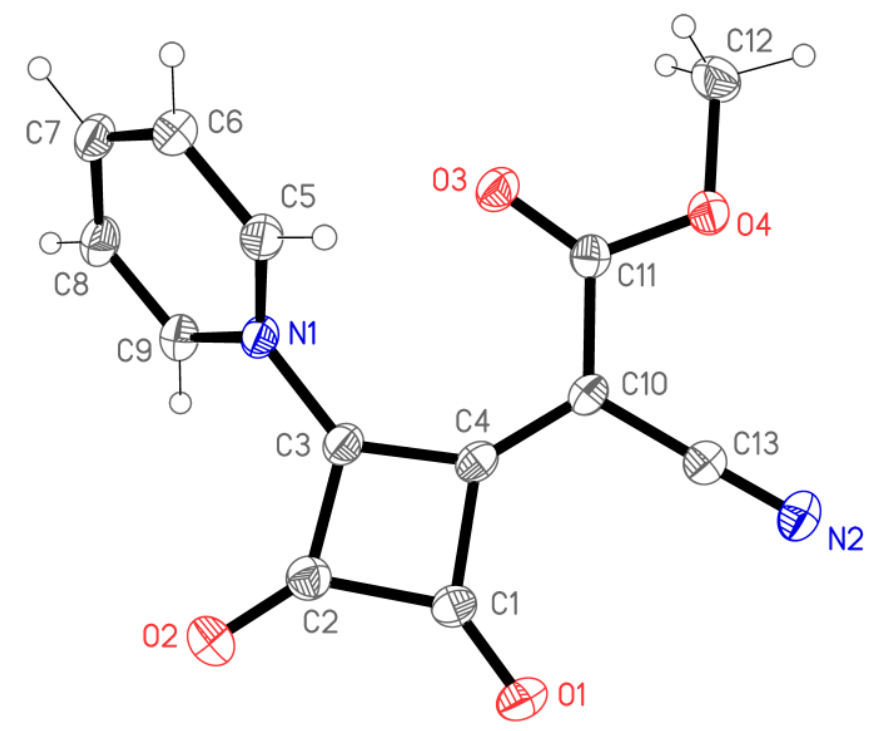

Figure 1. The molecule of compound 4 in the crystal. Ellipsoids represent $50 \%$ probability levels. Selected bond lengths $(\AA)$ and angles $\left(^{\circ}\right)$ : C1-O1 1.1999(14), C1-C4 1.5221(15), C1-C2 1.5452(16), C2-O2 1.2168(14), C2-C3 1.4427(15), C3-C4 1.4096(15), C3-N1 1.4221(14), C4-C10 1.3742(15); C4-C1-C2 88.33(8), C3-C2-C1 86.24(9), C4-C3-C2 97.05(9), C3-C4-C1 88.31(9).

Like other pyridinium ylides of squaric acid, 4 dissolves only in polar solvents, e.g., acetic acid or dimethylformamide, at high temperatures. Because of the electron delocalization, all representatives of this class of substances are intensely coloured. The UV/Vis-spectrum of a methanolic solution shows absorption maxima at 318 and $357 \mathrm{~nm}$.

\section{Materials and Methods}

\subsection{Materials}

Dichloromethane was dried over phosphorus pentoxide and distilled before use. Pyridine was dried over potassium hydroxide and distilled before use. Squaric acid dichloride was prepared by a literature procedure [10]. Other reagents and solvents were purchased from Acros Organics, Geel, Belgium, and were used without further purification.

\subsection{Instrumentation}

Melting points were determined in open-glass capillaries on an electric variable heater (Electrothermal IA 9100, Bibby Scientific, Stone, UK). FT-IR absorption spectra were recorded on a Thermo Nicolet FT-IR 200 spectrometer (Thermo Nicolet, Madison, WI, USA) using KBr pellets. 
${ }^{1} \mathrm{H}-\mathrm{NMR}$ and ${ }^{13} \mathrm{C}-\mathrm{NMR}$ spectra were recorded on a Bruker Avance DRX-400 (Bruker Corporation, Billerica, MA, USA) (NMR laboratories of the Chemical Institutes of the Technische Universität Braunschweig) using DMSO- $d_{6}$ as solvent. Chemical shifts are reported as parts per million (ppm) downfield from TMS used as an internal standard. Elemental analyses were recorded on a CE Instruments FlashEA®1112 Elemental Analyzer (Thermo Quest, San Jose, CA, USA). Mass spectra were recorded on a MAT 95 XL spectrometer (ThermoFinnigan MAT, Bremen, Germany, department of mass spectrometry of the Chemical Institutes of the Technische Universität Braunschweig). UV absorption spectra (200 to $600 \mathrm{~nm}$ ) were recorded on an PU 8700 UV/VIS Spectrometer in methanol. HPLC analyses were performed on a Merck Hitachi LaChrom Elite system (pump: L-2130, DAD detector: L-2450; autosampler: L-2200; column: Merck LiChroCART 125-4, LiChrospher $100 \mathrm{RP}-18(5 \mu \mathrm{m})$ (Merck, Darmstadt, Germany); eluent: acetonitrile/water (10:90), elution rate $1.000 \mathrm{~mL} / \mathrm{min}$; detection wavelength: $254 \mathrm{~nm}$ and $280 \mathrm{~nm}$; overall run time: $15 \mathrm{~min}$ ); $t_{\mathrm{ms}}=$ total retention time, $t_{\mathrm{s}}=$ dead time.

\subsection{Synthesis}

To an ice-cooled solution of squaric acid dichloride (1) $(1.51 \mathrm{~g}, 10.0 \mathrm{mmol})$ and methyl cyanoacetate (3) $(0.99 \mathrm{~g}, 10.0 \mathrm{mmol})$ in anhydrous dichloromethane $(10 \mathrm{~mL})$ was added dropwise a solution of pyridine (2) $(2.37 \mathrm{~g}, 30.0 \mathrm{mmol})$ in the same solvent $(15 \mathrm{~mL})$ at $0{ }^{\circ} \mathrm{C}$ over $30 \mathrm{~min}$. After stirring for $1 \mathrm{~h}$ at room temperature the resulting precipitate was filtered off and washed twice with propan-2-ol $(5 \mathrm{~mL})$. Crystallization from methanol/DMF yielded $1.15 \mathrm{~g} \mathrm{(44.9 \% )}$ of a brown solid.

M.p.: $250-252{ }^{\circ} \mathrm{C}$ (dec.); UV (methanol): $\lambda_{\max } 357 \mathrm{~nm}, \lambda_{\max } 318 \mathrm{~nm}$; MS (EI) $m / z$ (\%): 256 [M $\left.{ }^{+}\right]$(7), 79 (100); IR (KBr) $\left(\mathrm{cm}^{-1}\right): 2206(\mathrm{CN}), 1785,1773,1752,1695$ (C=O); ${ }^{1} \mathrm{H}-\mathrm{NMR}\left(400 \mathrm{MHz}, \mathrm{DMSO}-d_{6}\right)$ $\delta(\mathrm{ppm}): 8.92(\mathrm{~m}, 2 \mathrm{H}, \mathrm{ArH}), 8.67(\mathrm{tt}, 1 \mathrm{H}, J=1.4,7.8 \mathrm{~Hz}, \mathrm{ArH}), 8.23(\mathrm{~m}, 2 \mathrm{H}, \mathrm{ArH}), 3.51(\mathrm{~s}, 3 \mathrm{H}$, $\left.\mathrm{CH}_{3}\right) ;{ }^{13} \mathrm{C}-\mathrm{NMR}\left(100 \mathrm{MHz}, \mathrm{DMSO}-d_{6}\right) \delta$ (ppm): 194.1, 180.6, 172.4, 165.0, 157.4, 116.3, $67.5(\mathrm{C})$, 146.3, $143.3(2 \mathrm{C}), 126.4(2 \mathrm{C})(\mathrm{CH}), 51.4\left(\mathrm{CH}_{3}\right) ; \mathrm{HPLC}(\mathrm{AUC} \%): 99.7 \%$ at $254 \mathrm{~nm}, 99.9 \%$ at $280 \mathrm{~nm}$; $t_{m s}=5.53 \mathrm{~min} ; t_{s}=1.69 \mathrm{~min}$; Elemental analysis calculated for $\mathrm{C}_{13} \mathrm{H}_{8} \mathrm{~N}_{2} \mathrm{O}_{4}(256.21): \mathrm{C}, 60.94 \% ; \mathrm{H}, 3.15 \%$; $\mathrm{N}, 10.93 \%$; found: $\mathrm{C}, 60.68 \%$; $\mathrm{H}, 3.16 \%$;, $10.78 \%$. The supporting ${ }^{1} \mathrm{H}-\mathrm{NMR},{ }^{13} \mathrm{C}-\mathrm{NMR}, \mathrm{IR}, \mathrm{UV} / \mathrm{VIS}$ and mass spectra are presented in the supplementary material file.

\subsection{X-ray Structure Determination of $\mathbf{4}$}

Crystal data: Monoclinic, $P 2_{1} / n, a=10.37270(13), b=6.54287(9), c=17.0477(2) \AA, \beta=91.1876(12)^{\circ}$, $V=1156.73 \AA^{3}$ (at $\left.100 \mathrm{~K}\right), Z=4, D_{x}=1.471 \mathrm{Mg} \mathrm{m}^{-3}, \mu=0.95 \mathrm{~mm}^{-1}$.

A square plate-shaped crystal ca. $0.15 \times 0.15 \times 0.03 \mathrm{~mm}$ was mounted in inert oil on a glass fibre and transferred to the cold gas stream of the diffractometer (Oxford Diffraction Nova A using mirror-focussed $\mathrm{Cu}-K \alpha$ radiation). A total of 45,417 intensities were recorded to $2 \theta_{\max } 152^{\circ}$. Absorption corrections were implemented on the basis of multi-scans. The structure was refined anisotropically on $F^{2}$ using the program SHELXL-97 [11]. Hydrogens were included using rigid methyl groups or a riding model starting from calculated positions. Final $w R 2=0.091$ for 173 parameters and all 2415 unique reflections, $R 1=0.033[I>2 \sigma(I)], S=1.05$, max. $\Delta \rho=0.26 \mathrm{e}^{-3}$.

Supplementary Materials: CCDC-1556336 contains the complete supplementary crystallographic data. These data can be obtained free of charge from The Cambridge Crystallographic Data Centre via www.ccdc.cam.ac.uk/data_request/cif. The ${ }^{1} \mathrm{H}-\mathrm{NMR},{ }^{13} \mathrm{C}-\mathrm{NMR}, \mathrm{IR}, \mathrm{UV} / \mathrm{VIS}$ and mass spectra are available online at www.mdpi.com/1422-8599/2017/3/M953.

Acknowledgments: J.G. thanks C. Lechner for technical assistance.

Author Contributions: J.G.: Experimental synthetic work, synthesis planning, literature research, writing of manuscript; P.G.J.: X-ray structure determination, writing and proof reading of manuscript; C.K.: writing of manuscript.

Conflicts of Interest: The authors declare no conflict of interest. 


\section{References}

1. West, R.; Powell, D.L. New aromatic anions. III. Molecular orbital calculations on oxygenated anions. J. Am. Chem. Soc. 1963, 85, 2577-2579. [CrossRef]

2. Fatiadi, A.J. Synthesis of 1,3-(dicyanomethylene)croconate salts. New bond-delocalized dianion, "Croconate Violet". J. Am. Chem. Soc. 1978, 100, 2586-2587. [CrossRef]

3. Xia, G.; Wang, H. Squaraine dyes: The hierarchical synthesis and its application in optical detection. J. Photochem. Photobiol. C Photochem. Rev. 2017, 31, 84-113. [CrossRef]

4. Shafeekh, K.M.; Das, S.; Sissa, C.; Painelli, A. Asymmetric squaraine dyes: Spectroscopic and theoretical investigation. J. Phys. Chem. B 2013, 117, 8536-8546. [CrossRef] [PubMed]

5. Li, T.-Y.; Su, C.; Akula, S.B.; Sun, W.-G.; Chien, H.-M.; Li, W.-R. New pyridinium ylide dyes for dye sensitized solar cell applications. Org. Lett. 2016, 18, 3386-3389.

6. Kolev, T.M.; Yancheva, D.Y.; Stoyanov, S.I. Synthesis and spectral and structural elucidation of some pyridinium betaines of squaric acid: Potential materials for nonlinear optical applications. Adv. Funct. Mater. 2004, 14, 799-805. [CrossRef]

7. Grünefeld, J.; Zinner, G. Neue Oxokohlenstoff-Betaine der Quadratsäure. Chem.-Ztg. 1984, 108, 112.

8. Schmidt, A.H.; Aimène, A.; Schneider, M. Eine neue Klasse von Stickstoff-Betainen der Quadratsäure. Synthesis 1984, 436-439. [CrossRef]

9. Schmidt, A.H.; Straus, M.; Botzet, D. Oxokohlenstoffe und verwandte Verbindungen; 10. Mitteilung. Pseudooxokohlenstoff-Betaine der $\mathrm{C}_{4}$-Reihe mit einer Cyanamino- bzw. einer Sulfonylamino-Funktion durch Dreikomponenten-Reaktion. Synthesis 1985, 1055-1057. [CrossRef]

10. Lunelli, B. New, optimized preparation of 1,2-dichlorocyclobuten-1,2-dione $\left(\mathrm{C}_{4} \mathrm{O}_{2} \mathrm{Cl}_{2}\right)$ from squaric acid and oxalyl chloride. Tetrahedron Lett. 2007, 48, 3595-3597. [CrossRef]

11. Sheldrick, G.M. A short history of SHELX. Acta Cryst. 2008, A64, 112-122. [CrossRef] [PubMed]

(C) 2017 by the authors. Licensee MDPI, Basel, Switzerland. This article is an open access article distributed under the terms and conditions of the Creative Commons Attribution (CC BY) license (http:/ / creativecommons.org/licenses/by/4.0/). 